\title{
OBCIĄŻENIE STRONY KOSZTAMI POSTĘPOWANIA PRZED ORGANAMI PODATKOWYMI
}

\author{
Rafal Bernat*
}

Streszczenie:

W założeniu postępowanie podatkowe jest procedurą nieodpłatną dla podatnika, któremu umożliwiono obronę swojego sposobu interpretacji prawa podatkowego przed dwoma instancjami (organy podatkowe). Jeśli koszty postępowania wystąpią wskutek ekstraordynaryjnych środków dowodowych (np. oględziny), to wydatki z tym związane co do zasady pokrywa Skarb Państwa. Celem artykułu jest przedstawienie trybu ponoszenia niezbędnych wydatków postępowania podatkowego, zarówno przez Skarb Państwa, jak i też wyjątkowo przez podatnika. Organ podatkowy decydujący o wymiarze postępowania oraz liczebności m. in. czynności dowodowych w sprawie, powinien mieć jasne ustawowe wytyczne dotyczące sposobu organizacji kosztów proceduralnych. Dlatego też autor odnosi się do przesłanek pozytywnych i negatywnych, których wystąpienie umożliwia obciążenie podatnika kosztami postępowania podatkowego. Opisano również sytuacje wyłączające obowiązek ponoszenia wydatków związanych z nowymi dowodami, organizacją rozprawy podatkowej lub udziałem biegłych, tłumaczy. Autor odniósł się do możliwości wystąpienia przez podatnika z wnioskiem o zwrot nakładów poniesionych przez niego podczas udziału w postępowaniu. W konsekwencji prowadzonych badań nad tym zagadnieniem poruszono materię pojęć nieostrych (niedookreślonych) takich jak: „,interes publiczny” lub „,ważny interes podatnika". Jako postulat de lege ferenda przyjęto potrzebę sprecyzowania przez ustawodawcę pozytywnych przesłanek ustawowych umożliwiających obciążenie podatnika kosztami postępowania podatkowego.

Słowa kluczowe: koszty postępowania, procedura podatkowa, organ podatkowy.

\section{WPROWADZENIE}

W procedurze podatkowej podatnicy zwyczajowo mogą wnosić środki zaskarżania (odwoławcze) bez potrzeby ponoszenia opłat administracyjnych. Podatnik ma prawo do nieodpłatnego czynnego udziału w administracyjnym (po-

* Doktorant w Katedrze Prawa Finansów Publicznych Uniwersytetu Mikołaja Kopernika w Toruniu, doradca podatkowy. 
datkowym) postępowaniu na płaszczyźnie dwóch instancji. Jeśli pełnomocnikiem podatnika jest doradca podatkowy, należy uiścić opłatę skarbową w wysokości 17 zł (jednorazowo w danym postępowaniu). Pojęcie kosztów postępowania może kojarzyć się z procedurą karną, cywilną lub sądowo-administracyjną, w których koszty sądowe stanowią niekiedy duże obciążenie dla strony, której powództwo zostało oddalone lub która została uznana za winną (postępowania karne). Niemniej jednak polski ustawodawca zawarł w ostatnich rozdziałach (nr 23) Ordynacji podatkowej [Ustawa z dnia 29 sierpnia 1997 r... - zwana także OP] postanowienia umożliwiające obciążenie podatnika kosztami postępowania podatkowego. Niedostateczny poziom dokonanej wykładni doktrynalnej nie pozwala także odpowiedzieć na pytania - czy zawsze Skarb Państwa pokrywa koszty postępowania i jakie wydatki zwraca podatnikowi jeśli to on poniósł ich początkowy ciężar. Postanowienia zawarte w art. 267-270 OP są na tyle ogólnikowe, że uchybieniem wydaje się ominięcie przez interpretatorów prawa podatkowego problemów wynikających z konstrukcji norm prawnych w nich zawartych. Bynajmniej teza o braku zainteresowania zagadnieniem o kosztach postępowania podatkowego może wynikać z rzadkich przypadków zastosowania tych przepisów [Dowgier 2011: 337], zwłaszcza że w art. 270 OP mamy do czynienia z wystąpieniem klauzul generalnych prawa podatkowego, które nie ułatwiają procedury, zarówno organom, jak i podatnikom. Warto również zbadać charakter prawny kosztu postępowania podatkowego oraz jego implikacji na sytuację prawną strony postępowania. Celem artykułu jest przedstawienie sytuacji prawnej podatnika w kontekście ponoszonych przez Skarb Państwa kosztów procedury podatkowej. Autor zastanowi się nad wymiarem kosztów postępowania oraz możliwością wydania przez organ aktu administracyjnego obciążającego nimi podatnika. Następnie zbadać warto charakter postanowienia dotyczącego kosztów postępowania oraz tryb odwoławczy w tej materii przed organem II instancji. Publikacja swoim zakresem obejmie rozważania na temat możliwości zwrotu przez Skarb Państwa niektórych kosztów postępowania jakie poniósł podatnik. Po zgłębieniu powyższych zagadnień, słusznym wydaje się przedstawienie materii klauzul generalnych stosowanych w przepisach o kosztach postępowania. Aby przeprowadzić analizę naukową dotyczącą wspomnianej tematyki należy uprzednio zdefiniować pojęcie kosztów postępowania podatkowego.

\section{POJECIE KOSZTÓW POSTĘPOWANIA}

Zgodnie $\mathrm{z}$ art. 265 OP kosztami postępowania podatkowego są: koszty podróży, koszty związane z osobistym stawiennictwem strony, wynagrodzenie przysługujące biegłym i tłumaczom, koszty oględzin i doręczenia pism urzędo- 
wych. Wymienione wydatki ${ }^{1}$ można podzielić na ponoszone w celu umożliwienia stronie (świadkom) udziału w postępowaniu oraz te związane $\mathrm{z}$ gromadzeniem przez organ podatkowy materiału dowodowego. Takie określanie wydatków daje wyraz największym obciążeniom ekonomicznym jakie mógłby ponieść organ w razie długotrwałej procedury lub dużej liczby przeprowadzonych czynności dowodowych. Katalog kosztów postępowania podatkowego, ponoszonych przez Skarb Państwa, należy określać jako zbiór otwarty, do którego (w świetle art. $265 \S 2$ OP) organ może kwalifikować wedle własnej decyzji różne wydatki [Kwietko-Bębnkowski 2013: 632; Zalewski i Malezini 2013: 609-614]. Uznaniowość organu podatkowego ma jednak pewne granice związane $\mathrm{z}$ charakterem postępowania podatkowego. Organ nie może uznać za koszt postępowania wydatków poniesionych w ramach czynności sprawdzających, kontroli skarbowej lub kontroli podatkowej. Bezsprzeczne będzie także wykluczenie wydatków jakie wystąpiły w innym postępowaniu - choćby dotyczyły tej samej podstawy prawnej i osoby podatnika. Zasadność ponoszenia kosztów postępowania nie jest ograniczana przez możliwości płatnicze jednostki Skarbu Państwa lecz legalizm związany z uzasadnieniem ich zaliczenia w trybie art. $265 \S 2$ OP. Dlatego też kosztem postępowania nie będą opłaty związane $\mathrm{z}$ zastępstwem podatnika przez pełnomocnika profesjonalnego (adwokat, radca prawny, doradca podatkowy) w toczącym się postępowaniu podatkowym ${ }^{2}$. Wydatki powinny być niezbędne do prawidłowego przeprowadzenia postępowania podatkowego (tj. należy dopuścić poprzez to możliwość realizacji wszystkich zasad postępowania wymienionych w art. 120-129 Ordynacji podatkowej). Prym nad regułą celowości ponoszenia wydatków wiedzie zasada o ponoszeniu ciężaru tego kosztu przez Skarb Państwa [por. Wyrok WSA w Bydgoszczy z dnia 23 maja 2006 r...]. Jednakże w niektórych wypadkach, podmiotem który będzie odpowiedzialny zwrócić organowi koszty postępowania podatkowego może być podatnik. Skoro Ordynacja podatkowa nie daje jednoznacznej odpowiedzi co do przesłanek pozytywnych obciążenia strony kosztami postępowania, to należy dokonać analizy przedmiotowej kwestii (stosując wykładnie gramatyczną i doktrynalną przepisów).

${ }^{1}$ Zarówno w piśmiennictwie: Kaźmierski i Golec [2013: 613]; Dauter [2003: 32], orzecznictwie, np. Wyrok WSA w Bydgoszczy z dnia 27 stycznia 2004 r... [2005: 29], jak i w opinii organów podatkowych, np. Interpretacja indywidualna z dnia 1 lutego 2011 r..., synonimem terminu „koszty” w odniesieniu do postępowania podatkowego jest określenie ,wydatki”. Dlatego też w przedmiotowym artykule pojęcia te użyte zostaną zamiennie. Różnica pomiędzy terminem „koszty” a „wydatki” występuje m. in. na gruncie podatku dochodowego - szerzej Bernat [2014: 58-64].

${ }^{2}$ Por. Wyrok Sąu Apelacyjnego w Poznaniu z dnia 29 lipca 2010 r... Skarb Państwa może zostać obciążony kosztami zastępstwa w postępowaniu podatkowym jedynie w wyniku prawomocnego orzeczenia dotyczącego odszkodowania dla strony na zasadach ogólnych - Kaczmarek [2006: 5-10]. Zdaniem WSA w Poznaniu [Wyrok WSA w Poznaniu z dnia 7 maja 2008 r...] kosztami postępowania nie będzie rekompensata dla kuratora za poświęcony czas dla celów postępowania w zakresie lucrum cessans - jeśli kurator wykonuje także zawód adwokata. 


\section{WARUNKI OBCIĄŻENIA STRONY KOSZTAMI}

Artykuł 267 OP należy uznać za podstawę obciążenia strony kosztami postępowania. Kryteria umieszczona w tym przepisie stanowią swoistą przeciwwagę dla generalnej zasady o ponoszeniu kosztów przez Skarb Państwa, województwo, powiat lub gminę (art. 264 OP). Słusznie podnosi się, że pierwszeństwo w stosowaniu powinna mieć zasada wyrażona w art. 264 OP, podczas gdy art. 267 OP powinien być interpretowany zawężająco [por. Kalinowski (w:) Brzeziński i in. 2002: 856]. Procedura podatkowa nie jest dobrym przykładem realizacji zasady kontradyktoryjności - strony nie spierają się przed sądem czy niezależnym organem. Postępowanie to można przyrównać do procesu inkwizycyjnego $^{3}$, w którym podatnik musi wszelkimi sposobami udowodnić, iż powstanie obowiązku podatkowego (o którego powstanie oskarża go organ) nie miało miejsca w jego przypadku. Dlatego też negatywnie należy się odnieść do możliwości obciążania podatnika kosztami procedury, wskutek której ma zostać na niego nałożona nowa należność publicznoprawna [podobnie: Zdanowicz 2000: 27]. Jeśli organy podatkowe traktowałyby art. 264 OP pryncypialnie, to podatnik mógłby wyrażać niepokój mający swoje źródło w przedłużającej się procedurze - kiedy to sam z własnych środków musi ponieść koszt procesu rozstrzygania organu wnoszonych środków zaskarżania.

Warto jednocześnie zaznaczyć, że kosztami postępowania może być obciążona nie tylko strona (osoba fizyczna, osoba prawna, jednostka nieposiadająca osobowości prawnej), ale także spadkobiercy tej strony [Dowgier 2008: 55]. W myśl art. $268 \S 2$ OP jeżeli koszty postępowania są skutkiem działania kilku osób, to są oni wobec organu podatkowego odpowiedzialni solidarnie. Nie chodzi tu tylko o kilku uczestników postępowania, ale o podmioty, których działania implikują dodatkowe koszty dla organu. Jeśli organ umieszcza daną grupę podmiotów na jednej płaszczyźnie odpowiedzialności, to musi wykazać związek pomiędzy tymi osobami. Należy stwierdzić, że odpowiedzialność solidarna nie może być rozszerzona na pełnomocników ustawionych przez strony lub przedstawicieli ustawowych podatnika (kurator). Pełnomocnicy działają w imieniu strony (nie swoim) i ich zakres odpowiedzialności dotyczy miary rzetelności w wykonywaniu działań za podatnika. Oznacza to, że udzielając pełnomocnictwa strona ponosi pełną, osobistą i syngularną odpowiedzialność za działania wypełniające dyspozycję art. 267 OP.

Dokonując analizy przesłanek umożliwiających obciążenie podatnika kosztami postępowania można je podzielić na: wydatki zawinione przez stronę (wskutek zatajenia dowodów, złożenia wyjaśnień niezgodnych z prawdą, nie-

\footnotetext{
${ }^{3}$ Por. Kleczkowski [2002: 27]. Za nieprawidłową należy uznać tezę, według której orzecznictwo sądowo-administracyjne przyczyniało się poprzez wydawane wyroki do utrwalania inkwizycyjnego charakteru postępowania podatkowego - Tarno [1999: 180]; Olszowy [1997: 1].
} 
stawienia się na rozprawę), administracyjne (sporządzenie odpisów lub kopii), fakultatywne (z wniosku strony). Istnieją także wydatki przewidziane w odrębnych przepisach ${ }^{4}$, według których podatnik może ponieść koszt opinii biegłego co do wartości rynkowej przedmiotu opodatkowania. Za każdym razem gdy organ dokonuje przeniesienia ciężaru wspomnianych wydatków na podatnika, musi to uzasadnić w sposób szczegółowy wraz $\mathrm{z}$ podaniem algorytmu użytego do obliczenia wysokości kosztów [Wyrok WSA w Bydgoszczy z dnia 23 kwietnia 2013 r...]. Podatnik wnosząc o przeprowadzenie rozprawy podatkowej wszczyna procedurę szczególną w ramach postępowania odwoławczego. Oznacza to dla organu przedłużenie postępowania (do 3 miesięcy od chwili wniesienia odwołania) i wykonanie szeregu dodatkowych czynności dotyczących organizacji tejże rozprawy (zawiadomienie stron, świadków, biegłych) ${ }^{5}$. Jeśli podatnik (wydłużając postępowanie) ma zamiar jedynie odroczyć w czasie uprawomocnienie się decyzji dobrym rozwiązaniem będzie przesunięcie ciężaru kosztów związanych z rozprawą na wnioskodawcę. Organ może także przeprowadzić dowód na wniosek strony i obciążyć wydatkiem za przeprowadzenie dodatkowych czynności dowodowych podatnika. Jednakże możliwe jest to tylko w przypadku, gdy wydatek był zbędny, a wskutek wniosku podatnika zebrany materiał dowodowy nie uległ znacznej zmianie. Podatnik nie jest zobligowany do sprawdzania organu w zakresie kompletności dowodowej. Jeśli jednak strona zauważa taki defekt, to żądanie przeprowadzenia dowodu jest spowodowane zaniedbaniami organu i nie może skutkować obciążeniem kosztami strony. W niektórych przypadkach zatem wpływ podatnika na charakter ponoszonych wydatków będzie decydujący. Jeśli organ ma zamiar przeprowadzić dowód z opinii biegłego, to jeśli podatnik ma ponieść koszt tej opinii winien także współdecydować (a przynajmniej być poinformowany) o umowie z biegłym [por. Ciecierski (w:) Kandut i Sędkowska 2012: 446].

Może także wystąpić sytuacja, gdy podatnik zostanie pozbawiony możliwości zapoznania się ze zgromadzonymi dokumentami w swojej sprawie. Organ ma obowiązek doręczania wszystkich decyzji i postanowień w sprawie i nie ma podstaw, by (w razie dużej ilości tych dokumentów) obciążać podatnika kosztami za sporządzenie oryginałów. Inaczej, w sytuacji gdy podatnik wnioskuje o sporządzenie uwierzytelnionych kopii lub odpisów tych decyzji (np. dla innych osób nie będących uczestnikami postępowania) - organ - ma wręcz obo-

\footnotetext{
${ }^{4}$ Za odrębne przepisy należy uznać m. in. art. 19 ust. 4 Ustawy z dnia 26 lipca $1991 \mathrm{r...}$ i art. 6 ust. 4 Ustawy z dnia 09 września 2000 r... Za prawidłowy należy uznać pogląd Naczelnego Sądu Administracyjnego [Wyrok z 29 stycznia 2013 r...], że przepisy szczególne o wydatkach w postępowaniu podatkowym nie stanowią lex specialis w stosunku do Ordynacji podatkowej i nie należy ich traktować pryncypialnie. Przepisy OP winno się stosować odpowiednio w takich sprawach [Wyrok WSA w Gdańsku z dnia 8 grudnia 2010 r...].

${ }^{5}$ Szerzej o charakterze wydatków w rozprawie podatkowej - Biegalski [2007: 15] oraz Dańczak [2007: 39].
} 
wiązek przerzucania wydatku na podatnika ${ }^{6}$. Nie należy poczytywać tego jako opłatę skarbową lecz zwrot poniesionych przez organ podatkowy nakładów. Podatnik ma na celu oddać jedynie taką kwotę jaką poniósł organ (bez dodatkowych prowizji naliczanych przez urząd). Błędne wydaje się kwalifikowanie każdej kopii poświadczonej przez organ jako dokumentu podlegającemu opłacie $\mathrm{w}$ trybie art. 1 ust. 1 pkt. $1 \mathrm{~b}$ ustawy o opłacie skarbowej [Ustawa $z$ dnia 16 listopada 2006 r...], gdyż wydatek postępowania podatkowego nie spełnia ustawowych przesłanek kwalifikowania go jako opłaty skarbowej. Problem z wyznaczaniem granicy odpowiedzialności majątkowej podatnika za koszty procedury podatkowej uwidocznia się zwłaszcza przy okazji wydania postanowienia dotyczącego kosztów prowadzonego postępowania. Dlatego też ważnym wydaje się zwrócenie uwagi na materię wzruszalności ${ }^{7}$ aktów administracyjnych dotyczących kosztów postępowania podatkowego.

\section{WZRUSZALNOŚĆ POSTANOWIEŃ O KOSZTACH}

W świetle art. 270a OP organ podatkowy wydać może na dowolnym etapie postępowania postanowienie o kosztach postępowania - w zakresie przedmiotowym jaki uważa za stosowny do realizacji zasad postępowania podatkowego (vide art. 120-129 OP) ${ }^{8}$. Analiza treści przepisów Ordynacji podatkowej nie umożliwia odpowiedzi na to, jaka ma być treść postanowienia i o jakich kwestiach formalnych ma przesądzać. Organ może w drodze postanowienia obciążyć kosztami postępowania stronę lub rozłożyć na raty spłatę kosztów. Wydaje się, że powinno być wydane jedno postanowienie dotyczące obciążenia kosztami, sposobie i terminie ich zapłaty oraz podstawie obciążenia kosztami tego konkretnego podatnika. Zwłaszcza, że podatnik zostanie także obciążony kosztami egzekucyjnymi (art. 271 OP), jeśli nie zapłaci w terminie przedmiotowych kosztów wskutek braku przejrzystej treści postanowienia. Godnym rozważania wydaje się pogląd o bezprawności wydanego postanowienia o obciążeniu kosztami, jeśli organ uprzednio zawiadomił podatnika, że wstrzymanie się z dokonaniem danej (kosztownej) czynności dowodowej będzie skutkowało nałożeniem na podatnika kary grzywny w wysokości $2600 \mathrm{zl}$ (art. $262 \S 2$ pkt. 2 OP). Co prawda jest to niezgodne $\mathrm{z}$ ratio legis zasad postępowania podatkowego $(\mathrm{m}$. in.

\footnotetext{
${ }^{6}$ Por. Wyrok WSA w Warszawie z dnia 18 grudnia 2007 r... Cena jednostkowa za sporządzenie kopii nie powinna zawierać podatku od wartości dodanej-Wyrok WSA w Olsztynie z dnia 7 czerwca $2006 r$...

${ }^{7} \mathrm{~W}$ piśmiennictwie termin „wzruszalność” używa się jako instytucję, obejmującą wszystkie tryby uchylenia lub zmiany wadliwych lub prawidłowych decyzji administracyjnych - Adamiak [2002: 22]; Jendrośka [1980: 79]. Dla potrzeb artykułu należy rozumieć „wzruszalność” aktu jako możliwość uchylenia lub zmiany aktu administracyjnego (także wydanego w sprawie podatkowej) - por. Ochendowski [1998: 153]; Masternak [1999: 26-28].

${ }^{8}$ Por. Wyrok WSA w Biatymstoku z dnia 13 września 2007 r...; Dolata [2013: 200].
} 
praworządności, pewności prawa i przekonywania) jednak w rzeczywistości możliwe. Organ ma prawo do nakładania sankcji za wykazywanie braku aktywnego udziału podatnika w postępowaniu, gdy jego udział jest niezbędny (podatnik może jako jedyny złożyć oświadczenie o zaistniałym stanie faktycznym). Jednak w każdym takim przypadku organ nie może dyscyplinować podatnika do konkretnych działań jeśli ich istota stoi w sprzeczności z art. 123 OP (tj. prawem a nie obowiązkiem czynnego udziału strony). Dlatego też należy odnieść się negatywnie do prób wywierania nacisku na podatnika, aby ten składając wniosek o przeprowadzenie dowodu mógł być potem podmiotem, do którego kierowane jest postanowienie o obciążeniu kosztami postępowania. Do przedmiotowych postanowień dotyczących kosztów postępowania stosować powinno się odpowiednio art. $68 \S 1 \mathrm{OP}, \mathrm{tj}$. jeśli organ doręczył postanowienie w terminie 3 lat od końca roku kalendarzowego, w którym powstał obowiązek obciążenia kosztami strony.

\section{MOŻLIWOŚĆ ZWROTU PODATNIKOWI KOSZTÓW POSTĘPOWANIA}

Organ podatkowy może na wniosek strony zwrócić koszty podróży jedynie w zakresie jakie one przysługują podatnikowi, świadkowi, biegłemu lub tłumaczowi. Prawo do zwrotu nakładów jest ograniczone czasowo, a jego realizacja zależy od skierowania w zawitym terminie żądania do organu. Brak dopełnienia tego terminu skutkuje bezpowrotnie utratą roszczenia o zwrot wydatków. W świetle art. $266 \S 1$ OP w zw. z art. $265 \S 1$ pkt. 1 i 2 OP jeśli stroną postępowania jest spółka kapitałowa to może ona żądać zwrotu kosztów poniesionych przez wszystkich członków jej zarządu, których obecność była niezbędna (gdyż zgodnie z umową spółki występowała reprezentacja łączna). W odniesieniu do podatników, którzy są osobami fizycznymi należy przyznać rację argumentacji sądów administracyjnych [Wyrok WSA w Bydgoszczy z dnia 11 lutego 2009 r...; Wyrok WSA w Łodzi z dnia 18 czerwca 2007 r...], opowiadających się za osobistym charakterem prawa z wspomnianego przepisu. Oznacza to, że jeśli na rozprawę podatkową wyznaczoną ex catedra stawi się podatnik wraz z małżonkiem, to roszczenie o zwrot kosztów podróży przysługiwać będzie jedynie podatnikowi. Pomimo podatkowej odpowiedzialności solidarnej całym swoim majątkiem 9 , małżonkowie jako dwa odrębne podmioty podatkowe, nie moga występować z wnioskiem z art. 266 OP jako jeden podatnik. Odmiennie sytuacja ta wygląda gdy toczące się postępowanie prowadzone jest wobec obu małżon-

${ }^{9}$ Szerzej o odpowiedzialności podatkowej małżonków - Mariański [2000: 16] oraz Saltarius [2008: 28-30]. Zdaniem A. Masternak jeśli małżonkowie uczestniczą w postępowaniu, organ musi traktować ich taki jakby byli jedynym podmiotem, mogącym być reprezentowanym przez obu na przemian małżonków - Masternak [2003: 51]. 
ków (po uprzednim połączeniu spraw) i gromadzenie materiału dowodowego dotyczy obu z nich (wtedy znajdzie zastosowanie art. $133 \S 3 \mathrm{OP}$ ).

Warto także zastanowić się nad charakterem prawnym kosztów postępowania, które poniosła strona i możliwością interpretowania ich jako „szkody” wynikłej wskutek ponadwymiarowego charakteru danego postępowania podatkowego. Jeśliby przyjąć taką tezę, odpowiednio należałoby stosować art. 260 OP, wedle którego podatnik może dochodzić odszkodowania na zasadach ogólnych od organu podatkowego, który swoim postępowaniem naruszył bezpodstawnie jego prawa o charakterze ius cogens (norm bezwzględnie obowiązujących). Wedle obowiązującej linii orzeczniczej [Wyrok NSA z dnia 13 lipca 2006 r...], jeśli powstała szkoda to organ nie powinien jej naprawiać przy pomocy czynności podjętych w postępowaniu podatkowym, gdyż charakter tej procedury przeczy celowi rekompensaty (jako oddaniu, zwróceniu pewnej kwoty pieniężnej). Wykładnia gramatyczna art. 361 Kodeksu cywilnego [Ustawa z dnia 23 kwietnia 1964 r. Kodeks cywilny...], nie daje odpowiedzi na pytanie czy nienależnie poniesiony wydatek przez podatnika (w ramach postępowania podatkowego) stanowi szkodę. Aby powstała szkoda musi wystąpić związek przyczynowo-skutkowy pomiędzy działaniem organu a degradacją sytuacji majątkowej podatnika. Ponadto organ musiałby dokonać pomniejszenia aktywów podatnika w sposób ewidentny (zamierzony). Taki pogląd nie wydaje się jednak prawidłowy z uwagi na fakt, że wydatki ponoszone przez podatnika mają służyć realizacji zasady prawdy obiektywnej w postępowaniu podatkowym. Jeśli podatnik nie poniósłby danego kosztu, to istnieje prawdopodobieństwo, że jego sytuacja (wskutek braku środka dowodowego) uległaby pogorszeniu. Nie wydaje się więc możliwe - w obecnym stanie prawnym - wniesienie skutecznego powództwa do Sądu o odszkodowanie od organu podatkowego z uwagi na poniesione przez podatnika (nienależnie) wydatki.

\section{KLAUZULE GENERALNE W PRZEPISACH DOTYCZĄCYCH KOSZTÓW POSTĘPOWANIA PODATKOWEGO}

W razie zagrożenia możliwością niekorzystnej dla organów podatkowych interpretacji przepisów podatkowych, ustawodawca może (w procesie legislacyjnym lub poprzez nowelizację) wprowadzić do aktu normatywnego klauzule generalne, których celem (wedle judykatury ${ }^{10}$ ) jest możliwość uwzględnienia różnego rodzaju okoliczności faktycznych, które nie mogą w oderwaniu od konkretnego stanu faktycznego (sytuacji prawnie relewantnej) być oceniane raz na zawsze i w sposób jednakowy. Taka destynacja stosowania klauzul generalnych wydaje się wciąż aktualna także na gruncie prawa podatkowego. W art. $270 \S 1$

\footnotetext{
${ }^{10}$ Wyrok Sądu Najwyższego z dnia 29 marca 1979 r..., podobnie - Sąd Najwyższy w wyroku $z$ dnia 23 kwietnia 2004 r...
} 
OP organ podatkowy może za podstawę rozłożenia na raty należności z tytułu kosztów sądowych przyjąć wystąpienie ważnego interesu lub interesu publicznego. Wedle Naczelnego Sądu Administracyjnego [Wyrok NSA z 14.09.2001 r...] pojęcie ,interesu publicznego" jest wyrażeniem niedookreślonym, które nie może być interpretowane w sposób subiektywny przez podatnika. Strona pomimo możliwej bona fide (dobra wiara) nie może uzurpować sobie prawa do analizy klauzuli generalnej, która celowo została wprowadzona jako narzędzie legislacyjne zabezpieczające ustawodawcę przez lukami decyzyjnymi. Natomiast termin ,ważny interes” sąd określa [Wyrok NSA z dnia 21 maja 2003 r...; Wyrok WSA w Warszawie $z$ dnia 8 stycznia 2007 r..., 2007: 43] mianem nieostrego, odwołującego się do pozaprawnego pojęcia interesu podatnika. Określenie nieostry bądź niedookreślony nie należy poczytywać jako synonimów. Interes publiczny można interpretować jako wytyczne postępowania, określające wartości wspólne dla ogółu, tj. sprawiedliwość, bezpieczeństwo, praworządność. Jednakże przymioty nie są sprecyzowane w art. $270 \mathrm{OP}$, dlatego interes publiczny jest w tym wymiarze pozbawiony ram szczególnych (zakresu przedmiotowego). Bez podstawy jest teza o utożsamianiu interesu publicznego z interesem fiskalnym Skarbu Państwa, ponieważ to co wedle rachunkowych obliczeń może być dla państwa najkorzystniejsze, jednocześnie często godzi w dobro ogółu. Z drugiej strony, ważny interes (podatnika) ma wymiar jednostkowy i powinien być rozpatrywany w odniesieniu do konkretnego podatnika. Zdaniem organów podatkowych ${ }^{11}$, aby mówić o ważnym interesie podatnika muszą zajść nadzwyczajne przesłanki: trudna sytuacja finansowa, nieprzewidziane zdarzenie o charakterze vis maior (siła wyższa), które czynią sytuację prawną podatnika mniej korzystną niż w innych przypadkach. Prawidłową wydaje się teza A. Nita, że pojęcie „,ważnego interesu podatnika” jest szersze niż brak środków na zaspokojenie organu podatkowego ${ }^{12}$. Oznacza to, że zadaniem podmiotu nie jest jedynie regulowanie obciążeń podatkowych (w tym także ponoszenie ciężaru wydatków postępowania) i sytuację podatnika nie można precyzować przez pryzmat aktualnej możliwości płatniczej. Jednocześnie ,,ważny interes podatnika” mógłby być przejęty w znaczeniu pejoratywnym - jako potrzeba akceptacji żądań podatnika z pominięciem interesu innych. Takie interpretowanie określenia ,ważny interes podatnika" oznacza, że powołując się na tę klauzulę generalną organ może udzielając pewnych ulg zrównać prawa podatnika z takimi jakie przysługują pozostałym osobom. Wtedy jednak interes podatnika przeciwstawia interesowi prawnemu ${ }^{13}$, tj. ustawowych uprawnień (jednocześnie obowiązków) do

\footnotetext{
${ }^{11}$ Interpretacja indywidualna z 5 maja 2009 r... Podobnie Kępa [2011: 12].

12 Nita [2003: 37-40]. Interes podatnika nie można jedynie określać jako dążenie jednostki do minimalizowania obciążeń publicznoprawnych - Radzikowski [2006: 153].

${ }^{13}$ Por. J. Bartosiewicz [2010: 38-40] i Dauter (w:) Babiarz i in. [2013: 392-394]. Powoływanie się przez organ na złą sytuację finansów publicznych nie może stanowić jedynej przesłanki
} 
tworzenia takiego środowiska prawnego, w którym wszyscy podatnicy (niezależności od zdolności płatniczej) mają te same prawa. Należy zatem opowiedzieć się za występującym wyborem pomiędzy ,interesem publicznym” a „ważnym interesem podatnika". Skoro dając zadość żądaniu podatnika o rozłożenie na raty należności z tytułu kosztów postępowania podatkowego organ realizuje indywidualny interes podatnika, to jednocześnie wykazuje pewną obojętność wobec interesu publicznego. Jednak, w niektórych przypadkach ulga w natychmiastowej spłacie zobowiązań skutkować będzie poprawianiem zdolności płatniczej podatnika, a w przyszłości wzrostem kwoty podatku płaconego przez niego do Skarbu Państwa. Konkludując, obie klauzule generalne same w sobie stanowią wartość ambiwalentną dla podatnika. Dopiero działania organu oraz interpretacja $\mathrm{w}$ danym postępowaniu przepisu art. 270 OP może oznaczać (jeśli tak zdecyduje organ podatkowy) wypełnienie ważnego interesu podatnika przy jednoczesnym braku naruszania dyspozycji interesu publicznego [Mączyński 2005: 14].

\section{PODSUMOWANIE}

Koszty postępowania podatkowego to de facto wydatki jakie musi ponieść Skarb Państwa w realizacji ustalania wymiaru należności publicznoprawnej rezydenta (jeśli dotyczy to decyzji określającej zobowiązanie podatkowe). Pośrednio zatem podatnik ponosi ciężar takiego postępowania uiszczając podatki. Wspiera tą formą działanie i organizację organów podatkowych. Różnica w ponoszeniu ciężaru kosztów procedury podatkowej polega na momencie, w którym podatnik ten uszczupla swój majątek przekazując stosowną kwotę na rzecz Skarbu Państwa. Jeśli w konkretnym wypadku wątpliwe jest aby podatnik poniósł bezpośrednio koszty postępowania, to należy obciążyć nimi organy podatkowe [por. Dzwonkowski (w:) Kosikowski i in. 2003: 684]. Ciężar przedstawienia istotnego uzasadnienia dla odpowiedzialności podatnika za koszty postępowania spoczywa na organie podatkowym (dowodzi bowiem wyłączenia swoich obowiązków ustawowych). Klauzule generalne zawarte w przepisach dotyczących kosztów nie mogą być podstawą do subiektywnego wyboru osób mogących skorzystać z rozłożenia na raty. W obecnym stanie prawnym art. $267 \S 1$ pkt. 1 OP może być podstawą do nałożenia na stronę wydatków związanych z postępowaniem podatkowym. Jako postulat de lege ferenda należy uznać potrzebę sprecyzowania przesłanek umożliwiających zwolnienie Skarbu Państwa z obowiązku ponoszenia kosztów postępowania na rzecz podatnika. Należy również usunąć art. $267 \S 1$ pkt. 3 OP, który stoi w sprzeczności z zasadą czynnego udziału strony na każdym etapie postępowania oraz możliwością zapozna-

odrzucenia wniosku o rozłożenie na raty zobowiązania z tytułu kosztów postępowania podatkowego, por. Mastalski [2014: 47]. 
nia się przez podatnika $\mathrm{z}$ aktami sprawy. Charakter prawny tak istotnego dla podatnika zagadnienia jakim są koszty postępowania, w którym uczestniczy, powinny być zdefiniowane w Ordynacji podatkowej w sposób nie pozostawiający wątpliwości także dla przedstawicieli organów podatkowych oraz judykatury.

\section{BIBLIOGRAFIA}

Adamiak B., 2002, Nieważność aktu prawa miejscowego a wadliwość decyzji administracyjnej, „Państwo i Prawo”, z. 9.

Babiarz S., Dauter B., Gruszczyński B., 2013, Ordynacja podatkowa. Komentarz, Warszawa.

Bartosiewicz J., 2010, Problematyka udzielania ulg w spłacie zobowiazań podatkowych dotyczqcych podatków pobieranych przez urzędy skarbowe a stanowiacych dochody gmin, „Casus”, nr 57.

Bernat R., 2014, Koszty uzyskania przychodów w działalności prawniczej, „Zeszyty Naukowe Uczelni im. Marii Skłodowskiej-Curie", nr 3.

Biegalski A., 2007, Rozprawa w postępowaniu podatkowym - przebieg i konsekwencje, „Prawo i Podatki”, nr 1 .

Brzeziński B., Kalinowski M., Masternak M., Olesińska A., 2002, Ordynacja podatkowa. Komentarz, Toruń.

Dańczak P., 2007, Rozprawa administracyjna $w$ toku postępowania podatkowego, „Przegląd Podatkowy", nr 6.

Dauter B., 2003, Koszty postepowania podatkowego, „Glosa”, nr 13.

Dauter B., 2007, Ulgi w splacie zobowiazań podatkowych o charakterze solidarnym, „Casus”, nr 2.

Dolata S. (red.), 2013, Podstawy wiedzy o polskim systemie podatkowym, Warszawa.

Dowgier R., 2003, Koszty postępowania podatkowego, „Glosa”, nr 13.

Dowgier R., 2008, Decyzja o zakresie odpowiedzialności podatkowej spadkobiercy, (w:) L. Etel, Ordynacja podatkowa w teorii i praktyce, Temida 2, Białystok.

Dowgier R., 2011, Postępowanie w przedmiocie kosztów postępowania podatkowego, (w:) M. Popławski, Ordynacja podatkowa. Zagadnienia Proceduralne, Temida, Białystok.

Jendrośka J., 1980, Pojęcie decyzji administracyjnej i jej trwałość, (w:) L. Bar (red.), Problemy praworzadności $w$ działaniu administracji państwowej, Wrocław-Warszawa-Kraków -Gdańsk.

Kaczmarek K., 2006, Odpowiedzialność odszkodowawcza Skarbu Państwa - wynagrodzenie doradcy podatkowego jako element szkody, „Przegląd Podatkowy”, $\mathrm{nr} 4$.

Kandut K., Sędkowska A. (red.), 2012, Ustawa o kontroli skarbowej. Komentarz, Warszawa.

Kaźmierski A., Golec S., 2013, Postępowanie podatkowe: 810 wyjaśnień i interpretacji, Wolters Kluwer.

Kępa M., 2011, Skutki podatkowe klęski żywiołowej, „Radca Prawny”, nr 7.

Kleczkowski L., 2002, Koszty uzyskania przychodu a ciężar dowodu, „Monitor Podatkowy”, nr 8.

Kosikowski C., Dzwonkowski H., Huchla A., 2003, Ordynacja podatkowa. Komentarz, Warszawa.

Kwietko-Bębnkowski M., 2013, Ordynacja podatkowa: 366 wyjaśnień i interpretacji, Warszawa.

Mariański A., 2000, Odpowiedzialność matżonka i rozwiedzionego matzonka podatnika (płatnika, inkasenta) za zobowiazania podatkowe na gruncie Ordynacji podatkowej, ,Palestra”, nr 2-3.

Mastalski R., 2014, Prawo podatkowe, C. H. Beck, Warszawa.

Masternak A., 2003, Nowe pojęcie strony postępowania podatkowego, „Przegląd Podatkowy”, nr 3.

Masternak M., 1999, Wzruszalność ostatecznych decyzji podatkowych tworzacych prawa oraz nie tworzacych praw dla strony, ,Monitor Podatkowy”, $\mathrm{nr} 4$.

Mączyński D., 2005, Ochrona podatnika przed skutkami przepisów trudnych do zrozumienia, „Przegląd Podatkowy”, nr 12. 
Nita A., 2003, Glosa do wyroku SN z dnia 6 lutego 2002 r., III RN 198/00, „Glosa”, nr 2.

Ochendowski E., 1998, Wzruszalność ostatecznej decyzji podatkowej, (w:) Z. Chmiel (red.), Księga pamiątkowa ku czci docenta Eligiusza Drgasa, Studia z zakresu ordynacji podatkowej, TNOiK, Toruń.

Olszowy W., 1997, Decyzja podatkowa. Podejmowanie i kontrola, Warszawa.

Popławski M., 2011, Ordynacja podatkowa. Zagadnienia Proceduralne, Temida, Białystok.

Radzikowski K., 2006, Zasady podejmowania i kontroli sadowej decyzji w sprawie umorzenia zaległości podatkowych $w$ świetle uznania administracyjnego, „Kwartalnik Prawa Publicznego", $\mathrm{nr} 4$.

Radzikowski K., 2013, Wpływ prawa pomocowego na przesłanki i charakter decyzji w sprawie ulg w spłacie zobowiązań podatkowych, „Przegląd Podatków Lokalnych i Finansów Samorządowych", nr 5.

Saltarius S., 2008, Zaspokojenie wierzyciela podatkowego z majątku wspólnego podatnika i jego matżonka, ,Przegląd Podatkowy”, nr 4.

Tarno J. P., 1999, Naczelny Sąd Administracyjny a wykładnia prawa administracyjnego, Warszawa.

Zalewski D., Malezini A., 2013, Postępowanie podatkowe. 810 wyjaśnień i interpretacji, Wolters Kluwer.

Zdanowicz J., 2000, Koszty postępowania podatkowego, „Monitor Podatkowy”, nr 9.

\section{Akty normatywne}

Ustawa z dnia 09 września 2000 r. o podatku od czynności cywilnoprawnych, DzU 2010, nr 101, poz. 649, j.t.

Ustawa z dnia 16 listopada 2006 r. o opłacie skarbowej, DzU 2012, poz. 1282, j.t.

Ustawa z dnia 23 kwietnia 1964 r. Kodeks cywilny, DzU 2014, poz. 121, j.t.

Ustawa z dnia 26 lipca 1991 r. o podatku dochodowym od osób fizycznych, DzU 2012, poz. 361, j.t.

Ustawa z dnia 29 sierpnia 1997 r. Ordynacja podatkowa, DzU 2012, poz. 749, j.t.

\section{Orzecznictwo}

Wyrok NSA z dnia 13 lipca 2006 r., I FSK 1009/05, LEX nr 293207.

Wyrok NSA z dnia 14 września 2001 r., III SA 1590/00, Lex 79619.

Wyrok NSA z dnia 21 maja 2003 r., III SA 2752/01, Lex 145004.

Wyrok NSA z dnia 29 stycznia 2013 r., II FSK 1179/11, Lex nr 1298434.

Wyrok Sadu Apelacyjnego w Poznaniu z dnia 29 lipca 2010 r., I ACa 512/10, Lex 756632.

Wyrok Sadu Najwyższego z dnia 23 kwietnia 2004 r., I CK 550/03, Lex 188472.

Wyrok Sądu Najwyższego z dnia 29 marca 1979 r., III CRN 59/79, Lex 8176.

Wyrok WSA w Biatymstoku z dnia 13 września 2007 r., I SA/Bk 362/06, Lex 453512.

Wyrok WSA w Bydgoszczy z dnia 11 lutego 2009 r., I SA/Bd 776/08, Lex 483223.

Wyrok WSA w Bydgoszczy z dnia 23 kwietnia 2013 r., II SA/Bd 101/13, Lex 1351364.

Wyrok WSA w Bydgoszczy z dnia 23 maja 2006 r., I SA/Bd 198/06, Lex nr 302289.

Wyrok WSA w Bydgoszczy z dnia 27 stycznia 2004 r., SA/Bd 2855/03, „Biuletyn Skarbowy” 2005, nr 3.

Wyrok WSA w Gdańsku z dnia 8 grudnia 2010 r., I SA/Gd 860/10, Lex 748098.

Wyrok WSA w Łodzi z dnia 18 czerwca 2007 r., I SA/Łd 718/06, Lex nr 925948.

Wyrok WSA w Olsztynie z dnia 7 czerwca 2006 r., I SA/O1 223/06, Lex 237127.

Wyrok WSA w Poznaniu z dnia 7 maja 2008 r., I SA/Po 299/08, Lex 524054.

Wyrok WSA w Warszawie z dnia 18 grudnia 2007 r., I SA/Wr 1233/07, Lex 688880.

Wyrok WSA w Warszawie z dnia 8 stycznia 2007 r., III SA/Wa 2904/06, „Monitor Podatkowy” 2007, nr 11.

Wyrok z dnia 29 stycznia 2013 r., II FSK 1179/11, Lex nr 1298434. 


\section{Interpretacje podatkowe}

Interpretacja indywidualna z dnia 1 lutego 2011 r., IPPB3/423-774/10-2/DP

Interpretacja indywidualna z dnia 5 maja 2009 r. Dyrektora Izby Skarbowej w Katowicach, IBPBII/1/436-46/09/MZ.

\section{LOAD ON THE COSTS OF THE PROCEEDINGS BEFORE THE TAX AUTHORITIES}

In the tax procedure is the routine free of charge for the taxable person, to whom were given the opportunity to defend his way of interpretation of the tax law before two instances (the tax authorities). If the costs of the proceedings will occur as a result of extraordinary evidence (e.g. visual inspection) to the expenses associated with it, as a rule, shall be borne by the state treasury. The purpose of this article is to provide the necessary expenditure of tax proceedings bear mode by both the state treasury and also exceptionally by a taxable person. The tax authority for the dimension and size of among others steps of evidence on it should have a clear statutory guidance on how the organization the procedural costs. Therefore, the author refers to positive and negative evidence, which allows the taxpayer to pay tax treatment. See also exclusionary situations to incur any expenditure related to the new evidence, the organization tax hearing or participation of experts, translators. The author has suffered by the taxable person to the possibility of a request for reimbursement of costs incurred by him for participation in the proceedings. As a result of the study on this subject matter concepts discussed acute (interminate) such as: „public interest” or „important interest taxable person”. As postulate de lege ferenda has been adopted by the legislature need to clarify positive reasons laws enabling the taxpayer to pay tax treatment.

Key words: costs of proceedings, tax procedure, tax authority. 